\title{
Feedback regulation of antibody production: a role in rheumatoid arthritis?
}

\author{
J K Kalsi, N D Hall
}

Mechanisms controlling antibody synthesis in rheumatoid arthritis (RA) are defective. This is clear not only from the observations that hypergammaglobulinaemia and autoantibody formation are common findings in $\mathrm{RA}$, but also from the joint pathology where numerous plasma cells are actively synthesising immunoglobulin. ${ }^{1}$ Such observations have led to intensive investigations of the pathways that regulate antibody synthesis. Most of these have centred on $\mathrm{T}$ cell function and have shown that suppressor cell activity in RA is impaired, especially in the joint. ${ }^{2-6}$ Another mechanism exists, however, which is also important in controlling the antibody response-namely, Fc mediated negative feedback suppression. This process is often ignored in investigative studies of immunoregulation but should not be overlooked as defects here may adversely affect other control mechanisms. Idiotype-antiidiotype interactions are recognised as an important part of the immunoregulatory circuit and there is evidence that such control may be mediated through feedback suppression. ${ }^{7}$ This review considers the mechanisms underlying feedback inhibition and its possible role in the pathogenesis of RA. It should be appreciated that not all Fc mediated effects are suppressive. Thus complexes containing both $\operatorname{IgM}^{8}$ and IgG antibodies may enhance immune responses under certain conditions, and Weigle's group has reported extensively on a stimulatory fragment derived from human IgG-Fc. ${ }^{10-12}$

That antibody can regulate its own production has been known for nearly 100 years. Workers in the late 19th and early 20th centuries noted that preformed antigen-antibody complexes could either enhance or suppress the humoral response. Subsequent studies showed that passively administered antibody was able to suppress specifically the response to a given antigen. ${ }^{13-15}$ This was thought to occur through the masking of antigenic determinants by antibody-a concept supported by the observations that higher affinity antibodies were more effective than those of lower affinity ${ }^{16}$ and that $F\left(a b^{\prime}\right)_{2}$ was reported to be equipotent with the whole IgG molecule. ${ }^{17}$ Other data emerged, however, which suggested a different mechanism. Uhr and Bauman showed that antibody injected five days after immunisation was still able to suppress the immune response, suggesting that a feedback mechanism was operating. ${ }^{18}$ In addition, Sinclair reported that $F\left(a b^{\prime}\right)_{2}$ was 1000 -fold less effective than intact IgG in causing suppression and that this difference lay in the presence of the Fc portion. ${ }^{19}$ These conflicting data were united by Hoffman and Kappler, ${ }^{20}$ who postulated that antibody mediated suppression operated at two levels: antigen masking did occur at high concentrations of antibody, but at low levels, where this was ineffective, an Fc dependent mechanism came into play.

Exactly how this suppression occurs and the Fc receptor involved are unclear. Three distinct types of Fc receptors have been identified on human leucocytes, ${ }^{21}$ with Fc receptor II predominating on B lymphocytes. Two mechanisms for Fc mediated suppression have been proposed: one suggests that this occurs by interference with $T-B$ cell cooperation ${ }^{22}$ and the other advocates direct $B$ cell blockade. ${ }^{23}$ Although there is evidence to support both these mechanisms, many of the recent reports have concentrated on the latter pathway. In 1971 Sinclair and Chan proposed a tripartite inactivation model to show how B cell blockade might occur. ${ }^{24}$ It was suggested that immune complexes were able to bind to B lymphocytes via both the antigen receptors (surface immunoglobulin) and Fc receptors. Cross linking of these two entities was thought to inactivate the cell. Subsequent investigators demonstrated this using various Fc receptor ligands. ${ }^{25}$ The lymphocytes are thought to be diverted from plasma cell formation to memory cell generation. ${ }^{23}$ Indeed it has been recognised that immune complexes, although effectively suppressing the primary response, are highly efficient in allowing priming of lymphocytes in preparation of the secondary response. ${ }^{26}$ An alternative view invoking a factor derived from B cells exposed to IgG aggregates in the suppressive mechanism has also been reported. ${ }^{27}$

The exact nature of the negative signal delivered by immune complexes is not yet known. Antigen receptors on B cells belong to a class of $\mathrm{Ca}^{2+}$ mobilising receptors. ${ }^{28}$ Ligandreceptor interaction causes the activation of a membrane phosphoinositol bisphosphate diesterase through a $\mathrm{G}$ protein, ${ }^{29} 30$ leading to hydrolysis of membrane phosphoinositol bisphosphate to generate second messengers inositol trisphosphate and diacylglycerol..$^{31-33}$ The former causes release of $\mathrm{Ca}^{2+}$ ions from intracellular stores, ${ }^{34}$ whereas the latter activates the $\mathrm{Ca}^{2+}$ dependent protein kinase $\mathrm{C}^{35}$ which causes phosphorylation of proteins and hence cell activation. Using antibodies to IgM, Bijsterbosch and Klaus found that cross linking of $\mathrm{Fc}$ receptors and surface immunoglobulin on murine B cells inhibits cell activation by preventing second messenger generation. ${ }^{36}$ This is thought to occur through the uncoupling of antigen receptors from an as yet undefined $G$ protein, $\mathrm{Gp} .^{37}$

There is evidence to suggest that $T$ cell 
factors may interfere with feedback inhibition of antibody synthesis. Earlier investigations showed that the presence of factors that provide T cell 'help' (tumour necrosis serum) was able to prevent suppression. ${ }^{19}$ There is evidence to show that the cytokine $T$ cell replacing factor can bind to Fc receptors. ${ }^{38}$ It was suggested that the outcome of B cell activation depends on competition between $\mathrm{T}$ cell replacing factor and immune complexes at the $\mathrm{Fc}$ receptor site. ${ }^{22}$ More recently, interleukin 4/B cell stimulating factor 1 has been shown to reverse feedback suppression in a small number of murine B cells, whereas B cell growth factor II, which is synonymous with $T$ cell replacing factor, ${ }^{39}$ had no effect. ${ }^{40}$ That $T$ cells can affect feedback inhibition is also indicated by Sinclair and Panoskaltsis, ${ }^{41}$ who found that blocking of Fc binding by antibody to $\mathrm{Fc}$ dramatically reduced the number of $T$ cells required to generate an immune response to a $T$ cell dependent antigen. Thus part of the $\mathrm{T}$ cell 'help' generated during a normal immune response is apparently needed to overcome the downregulated state of $B$ cells.

Investigations of feedback suppression in patients with rheumatoid arthritis have been rather limited. Patients with rheumatoid disease are reported to have increased ${ }^{42}$ or normal levels of Fc receptor expression. ${ }^{44}$ Using a modified rosette assay, we have shown that the increased levels of Fc receptor expression may in part be due to significantly raised numbers of cells expressing receptors for the $\mathrm{CH} 2$ region of rabbit IgG (Facb-R + cells). ${ }^{45}$ These bear neither $\mathrm{T}$ nor $\mathrm{B}$ cell markers but do possess certain monocyte related antigens and exhibit major histocompatibility complex class II antigens. ${ }^{46}$ Similar cells have been described as OKM1 + granular lymphocytes by Cooper and colleagues. ${ }^{47}$ Facb-R + cells have been shown to be involved in feedback suppression using both murine ${ }^{48}$ and human cell systems, ${ }^{49}$ and the increase in Facb-R+ cells in rheumatoid patients might therefore be thought to reflect the attempt of the immune system to control B cell hyperactivity. When feedback suppression of in vitro IgG synthesis was examined in these subjects, however, it was found to be significantly impaired compared with that in healthy controls. ${ }^{49}$ Patients with ankylosing spondylitis or osteoarthritis showed normal feedback suppression of IgG production, as did patients with early (less than two years) RA. ${ }^{50}$ Other workers have also shown impaired Fc receptor dependent regulation of $B$ cells in RA. ${ }^{51}$ Two main conclusions thus emerge from these data: firstly, Fc receptor expression and the ability to suppress through feedback inhibition are not directly related and, secondly, a process associated with disease chronicity rather than the disease itself is involved in the impaired feedback suppression noted in established RA. Whatever the mechanism, it is clear that Fc receptor signalling is impaired in RA as neutrophils from rheumatoid subjects show reduced $\mathrm{Ca}^{2+}$ ion fluxes when triggered by coligation of $\mathrm{Fc}$ receptor with antibodies to either $\mathrm{Fc}$ receptor II or Fc receptor III. ${ }^{52}$ It may be that in a chronically stimulated immune system B lymphocytes become refractory to negative signals delivered through the Fc receptors. For example, it has been shown that Fc receptor mediated suppression of $B$ cell activity is impaired in NZB mice where autoimmune and B cell hyperactivity occur spontaneously. ${ }^{53}$

In vivo, the efficiency of feedback suppression will depend not only on Fc receptors but also on the properties and availability of antibody. In RA agalactosyl IgG has been found in high concentrations in patients with active disease. ${ }^{54}$ These IgG molecules cannot bind to Fc receptors $^{55} 56$ and therefore do not participate in feedback suppression. ${ }^{57}$ It is of considerable interest that a significantly higher proportion of patients with early synovitis with agalactosyl IgG were subsequently found to develop RA compared with those with normal IgG (Young A et al, unpublished data). It is likely that a defect in feedback suppression in established RA may be further exaggerated in vivo by the presence of IgM rheumatoid factor. This autoantibody is produced in response to normal immunisation $^{58} 59$ and may, it has been suggested, have a role in preventing feedback suppression, thus allowing maximal development of an immune response. ${ }^{60}$ In RA persistently high levels of rheumatoid factor may restrict the amount of antibody available for feedback suppression.

In conclusion, feedback inhibition of antibody production in patients with established RA is depressed. This is in part related to the impaired function of regulatory cells, possibly reflecting poor $\mathrm{Fc}$ receptor signal transduction. Rheumatoid IgG, however, may be less able to deliver an effective negative signal owing to its partially deglycosylated state. Other factors associated with chronic rheumatoid inflammation may also disrupt feedback suppression through competition for the relevant binding sites. These include rheumatoid factor interacting with IgG-Fc and cytokines binding to Fc receptors. Clearly, much more needs to be done to evaluate the significance of feedback suppression in the overall process of immunoregulation and its dysfunction in rheumatoid disease.

1 Munthe E E, Natvig J B. Immunoglobulin classes, subclasses and complexes of IgG rheumatoid factor in rheumaclasses and complexes of IgG rheumatoid factor in theuma-

2 Chattopadhyay C, Chattopadhyay H, Natvig J B, Michaelsen T E, Mellbye $\mathrm{O} J$. Lack of suppressor cell activity in T E, Mellbye O J. Lack of suppressor cell activity in
rheumatoid synovial lymphocytes. Scand F Immunol 1979;
10: 309-16.

3 Chattopadhyay C, Chattopadhyay H, Natvig J B, Mellbye $O$ J. Rheumatoid synovial lymphocytes lack concanavalinA-activated suppressor cell activity. Scand f Immunol 1979; 10: 479-86.

4 Abdou N I, Lindsley H B, Luz S R, Pascual E, Hassanein $\mathrm{K}$ M. Suppressor $\mathrm{T}$ cell dysfunction and anti-suppressor cell antibody in active early rheumatoid arthritis. $\mathcal{F}$ Rheumatol 1981; 8: 9-19.

5 Romain P L, Burmester G R, Enlow R W, Winchester R J. Multiple abnormalities in immunoregulatory function of synovial compartment $T$ cells in patients with rheumatoid arthritis: recognition of a he

6 Sakane T, Takeda S, Murakawa Y, Kotani H, Honda M, Ueda $Y$. Analysis of suppressor $T$ cell function in patients with rheumatoid arthritis: defects in production of and responsiveness to concanavalin-A-ind
cells. $\mathcal{F}$ Immunol 1982; 129: 1972-7.

7 Kohler H, Richardson B C, Rowley D A, Smyk S. Immune response to phosphorylcholine. III. Requirement of the Fc portion and equal effectiveness of IgG subclasses in antireceptor antibody-induced suppression. F Immunol 1977; 119: $1979-86$. 
8 Powell R, Hutchings P, Cooke A, Lydyard P M. Antibody mediated regulation of immune responses. I. Enhancement of specific antibody responses through IgM antibodies. Immunol Lett 1982; 4: 253-8.

9 Carvalho E M, Davis J S IV, Horwitz D A. Conditions required for Fc-dependent immune complex enhancement of antigen-specific lymphocyte blastogenesis. $\mathcal{f}$ Immunol 1980; 124: 565-70.

10 Morgan E L, Weigle W O. Polyclonal activation of human B lymphocytes by Fc fragments. I. Characterization of the cellular requirements for $\mathrm{Fc}$ fragment-mediated polyclona antibody secretion by human peripheral blood B lymphocytes. F Exp Med 1981; 154: 778-90.

11 Morgan E L, Weigle W O. Potentiation of specific human in vitro immune responses by the Fc portion of human immunoglobulin. Clin Exp Immunol 1983; 53: 505-11.

12 Morgan $E \mathrm{~L}$, Weigle W $\mathrm{O}$. Biological activities residing in the Fc region of immunoglobulin. Adv Immunol 1987; 40: 61-134.

$13 \mathrm{Uhr} \mathrm{J} \mathrm{W}$, Moller G. Regulatory effect of antibody on the immune response. Adv Immunol 1968; 8: 81-127.

14 Chang H, Schneck S I, Brody N, Deutsch A, Siskind G W. Studies on the mechanism of the suppression of active antibody synthesis by passively administered antibody. f Immunol 1969; 103: 37-41.

15 Cerottini J C, McConahey P J, Dixon F J. Specificity of the immunosuppression caused by passive administration of antibody. F Immunol 1969; 103: 268-75.

16 Walker J G, Siskind G W. Studies on the control of antibody synthesis: effect of antibody affinity upon its ability to suppress antibody formation. Immunology 1968; 14: 21-8.

17 Tao T W, Uhr J W. Primary type antibody response in vitro. Science 1966; 151: 1096-8.

18 Uhr J W, Bauman J B. Antibody formation. I. The suppression of antibody formation by passively administered pression of antibody formation by passive
antibody. F Exp Med 1961; 113: 935-57.

19 Sinclair N R St C. Regulation of the immune response. I. Reduction in ability of specific antibody to inhibit long lasting IgG immunological priming after removal of the Fc fragment. $\mathcal{F} \operatorname{Exp}$ Med 1969; 129: 1183-201.

20 Hoffman M K, Kappler J W. Two distinct mechanisms of immune suppression by antibody. Nature $1978 ; 272$ : 64-5

21 Unkeless J C, Scigliano E, Freedman V H. Structure and function of human and murine receptors for IgG. Annu Rev Immunol 1988; 6: 251-81.

22 Hoffman M K. Antibody regulates the co-operation of B cells with helper cells. Immunol Rev 1980; 49: 79-91.

23 Kolsch E K, Oberbarnscheidt J, Bruner K, Heuer J. The Fc receptor: its role in the transmission of differentiation receptor: its role in the transmission

24 Sinclair N R St C. Chan P L. Regulation of the immune response. IV. The role of the Fc-fragment in feedback response. IV. The role of the Fc-fragment in feedback
inhibition by antibody. Adv Exp Med Biol 1971; 12: 609-15.

25 Phillips N E, Parker D C. Cross-linking of B lymphocyte Fcy receptors and membrane immunoglobulin inhibits antiimmunoglobulin-induced blastogenesis. f Immunol 1984 132: 627-32

26 Safford J W, Tokunda S. Antibody mediated suppression of the immune response. Effect on the development of
immunological memory. F Immunol 1971; 107: 1213-25.

27 Pisko E J, Turner J L, White R E, Parett M, Turner R A Suppression of a pokeweed mitogen stimulated plaque forming cell response by a human B lymphocyte derived aggregated IgG-stimulated suppressor factor: suppressive B cell factor (SBF). I Immunol 1986; 136: 2141-50.

28 Cambier J C, Justement L B, Newell K, et al. Transmembrane signals and intracellular "second messengers" in the signals and intracellular "second messengers" in the regulation of quiescent

29 Gold M R, Jakway J P, de Franco A L. Involvement of a guanine nucleotide-binding component in membrane IgMstimulated phosphoinositide breakdown. F Immunol 1987 139: $3604-13$.

30 Harnett M M, Klaus G G B. G protein coupling of antigen receptor-stimulated polyphosphoinositide hydrolysis in $B$ cells. F Immunol 1988; 140: 3135-9.

31 Ransom J T, Harris L K, Cambier J C. Anti-Ig induces release of inositol 1,4,5-triphosphate which mediates mobilisation of intracellular $\mathrm{Ca}^{++}$stores in $\mathrm{B}$ lymphocytes. f Immunol 1986; 137: 708-14.

32 Bijsterbosch M K, Meade J C, Turner G A, Klaus G G B $B$ cell lymphocyte receptors and polyphosphoinositide degradation. Cell 1985; 41: 999-1006.

33 Coggeshall K M, Cambier J C. B cell activation. VIII Membrane immunoglobulins transduce signals via activation of phosphatidylinositol hydrolysis. F Immunol 1984; 133: 3382-6.

34 Berridge $M$ J, Irvine $R$ F. Inositol triphosphate: a nove second messenger in cellular signal transduction. Natur 1984; 312: 315-21.

35 Nishizuka $\mathrm{Y}$. The role of protein kinase $\mathrm{C}$ in cell surface signal transduction and tumour promotion. Nature 1984 308: 693-7.

36 Bijsterbosch M K, Klaus G G B. Cross-linking of surface immunoglobulin and Fc receptors on B lymphocytes inhibits stimulation of inositol phospholipid breakdown via the antigen receptors. F Exp Med 1985; 162: 1825-36.

37 Klaus G G B, Harnett M M, Rigley K P. G-protein regulation of polyphosphoinositide breakdown in B cells. Proceedings of the 2nd international conference on lymphocyte activation. of the 2nd international conference on lymphoc

38 Schimpl A, Wecker E, Hubner L, Hunig Th, Muller G. Properties and mode of action of $T$ cell replacing factor (TRF). In: Mandel T E, et al, eds. Progress in immunology. Vol III. Canberra: Australian Academy of Science, 1987: $397-409$.

39 Kinashi T, Harada N, Severinson E, et al. Cloning of complementary DNA encoding T-cell replacing factor and identity with B-cell growth factor II. Nature 1986; 324: $70-5$.

40 O'Garra A, Rigley K P, Holman M, Mclaughlin J B, Klaus G G B. B cell stimulatory factor I reverses Fc receptormediated inhibition of B-lymphocyte activation. Proc Nat Acad Sci USA 1987; 84: 6254-8.

41 Sinclair N R St C, Panoskaltsis A. Interference with Fc signals increases an antibody response by $\mathrm{T}$ cell-deprived cultures to a T-dependent antigen. Cell Immunol 1987; 107: cultures

42 Wooley P H, Panayi G S. Studies of lymphocytes in rheumatoid arthritis. I. Uptake of ${ }^{125}$ I-heat aggregated human IgG by Fc receptor bearing lymphocytes. Ann Rheum Dis 1978; 37: 343-6.

43 Shapiro R K C, Wilson J D. Increased EA-rosette formation by lymphocytes from patients with rheumatoid arthritis. Clin Exp Immunol 1977; 29: 205-12.

44 Burmester G K, Kalden J R, Peter H H, Schedel I, Beck P Wittenborg A. Immunological and functional characteristics of peripheral blood and synovial fluid lymphocytes from patients with

45 Hall N D, Winrow V R, Bacon P A. Lymphocytes bearing Fc receptors in rheumatoid arthritis. I. An increased Fc receptors in rheumatoid arthritis. I. An increased Subpopulation of cells in rheumatoid arthritis detect

46 Winrow V R, Eales L-J, Hall N D, Goulding N J Hunneyball I M. Lymphocytes bearing Fc receptors in rheumatoid arthritis. II. Phenotypic characterisation of mononuclear cells forming Facb rosettes in RA. Ann Rheum Dis 1985; 44: 2-7.

47 Cooper S M, Roessner K, Ferriss J A, Baigent G, Bakke A C Increase in OKM 1 + granular lymphocytes in patients with rheumatoid arthritis. Arthritis Rheum 1987; 30: 1089-96.

48 Eales L-J, Hall N D, Hunneyball I M. Facb-rosette forming cells in mice: studies on their functional significance. Immunology 1984; 52: 17-24.

49 Eales L-J, Goulding N J, Hall N D, Winrow V R, Hunneyball I $M$. Lymphocytes bearing Fc receptors in rheumatoid arthritis. III. Immunoregulatory function associated with Facb-rosette forming cells. Ann Rheum Dis 1985; 44: 8-12.

50 Kalsi J K, Woolf A D, Hall N D. Factors affecting FcR mediated feedback suppression of antibody synthesis in rheumatoid arthritis (RA). Br $\mathcal{F}$ Rheumatol 1989; 28 (supp 2): 33

51 White R E, Pisko E J, Foster S L, Panetti M, Turner R A Decreased suppressive $B$-cell factor (SBF) in rheumatoid arthritis: evidence for a defect in B cell autoregulation. f Immunol 1986; 136: 2151-7.

52 Goulding N J, Godolphin J L, Guyre P M. Calcium ion mobilisation induced by neutrophil $\mathrm{F}_{\mathrm{C}} \gamma$ receptor co-ligation is impaired in rheumatoid arthritis (RA). Br $\mathcal{f}$ Rheumatol 1989; 28 (suppl 2): 91 .

53 Uhr F, Dickler H B. Independent ligand occupancy and cross-linking of surface Ig and Fcy receptors downregulates B-lymphocyte function. Evaluation in various B-

54 Parekh R B, Isenberg D A, Ansell B M, Roitt I M, Dwek R A, Rademacher $T$ W. Galactosylation of IgG associated jligosaccharides is reduced in patients with adult and juvenile onset rheumatoid arthritis and is related to disease activity. Lancet 1988; i: 966-9.

55 Tsuchiya N, Endo T, Matsuta K, et al. Effects of galactose depletion from oligosaccharide chains on immunological activities of human IgG. 7 Rheumatol $1989 ; 16$ : 285-90.

56 Nose $M$, Wigzell $H$. Biological significance of carbohydrate chains on monoclonal antibodies. Proc Natl Acad Sci USA 1983; 80: 6632-6.

57 Heyman B, Nose $M$, Weigle W O. Carbohydrate chains on IgG2b: a requirement for efficient feedback suppression. f Immunol 1985; 134: 4018-23.

58 Nemazee D A. Immune complexes can trigger specific $T$ celldependent autoanti-IgG antibody production in mice f Exp Med 1985; 161: 242-56.

59 Coulie P G, Van Snick J. Rheumatoid factor (RF) production during anamnestic immune responses in the mouse. III Activation of RF precursor cells is induced by their interaction with immune complexes and carrier-specific helper T cells. F Exp Med 1985; 161: 88-97.

60 Sinclair N R St C, Panoskaltsis A. Immunoregulation by Fc signals. A mechanism for self-non-self discrimination. Immunol Today 1987; 8: 76-9. 